\title{
An Interdisciplinary Curriculum Conversation on Fear and Learning
}

Theodore M. Christou and Judy Wearing

Queen's University

\begin{abstract}
Two curriculum scholars of contrasting epistemological backgrounds engage in a complicated curriculum conversation on the subject of fear and learning. One author's position is that learning is not only fraught with fear but also requires fear to be transformational. Furthermore, education is intimately connected to fear and unrest. The other author's position is that learning is biologically adaptive, generally of benefit to individuals and pleasurable under natural conditions. Societal learning among humans occurs relatively quickly, though never quick enough to keep pace with changes in the environment. The dialogue results in newfound recognition of the nature and power, of our perspectives on the one hand and the nature of curriculum conversation itself on the other hand.
\end{abstract}

Keywords: curriculum; philosophy of education; evolutionary biology; fear; learning

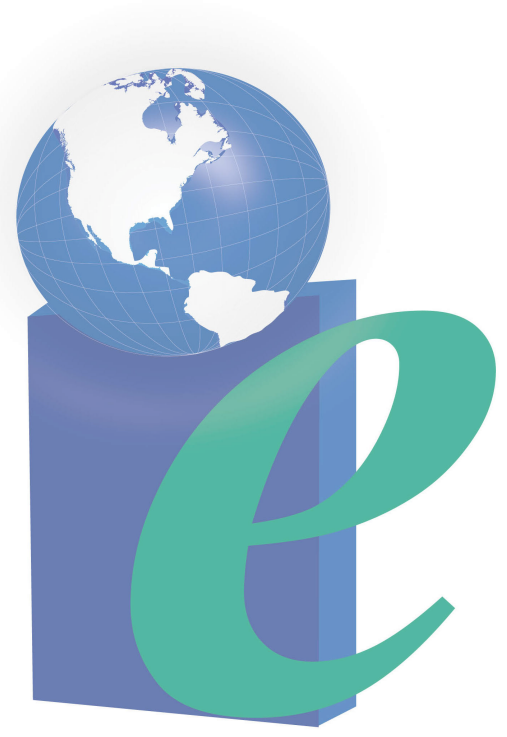




\section{An Interdisciplinary Curriculum Conversation on Fear and Learning}

We are two curriculum scholars engaging in dialogue despite having dissimilar educational backgrounds, which are grounded in unique epistemological foundations. Judy has come to the field of education after doctoral studies in evolutionary biology, whereas Theodore was trained as a philosopher and is currently a faculty member in curriculum history. Each draws on a distinct set of theorists, presumptions, and ways of understanding the world. Notwithstanding the dissimilarities between our disciplinary training and the worldviews we use to make sense of the world, the purpose of this paper is to detail a conversation between us, Judy and Theodore, on the relationship between fear and learning. This academic exchange of ideas occurred over a period of eight months, both in person and in print. The catalyst for this study was a casual conversation between Judy and Theodore early in the academic year. Theodore stated that learning is fearful and Judy disagreed. Beginning with these original positions, we exchanged a series of short written arguments, wherein each of us drew from our own disciplinary expertise in order to further elaborate our understanding of fear and learning and to try to convince the other that their position was faulty. The exchange considered learning at a micro and a macro level, exploring both the individual and society at large.

Theoretically, we frame our exchange as a curriculum conversation. Conversation is the dominant metaphor for the field of curriculum in a post-reconceptualist paradigm (Christou \& DeLuca, 2013; Pacheco, 2012; Sameshima \& Leggo, 2013) and it has been used by scholars to talk amongst themselves, often colloquially, to further a common understanding of subjects of interest (Gergen \& Jones, 2008; Jardine \& Ross, 2009; Lund \& Veinotte, 2010; Wiebe \& Guiney Yallop,2010). Here, we use the metaphor of conversation as a theoretical framework to foster dialogue between scholars with distinct epistemological viewpoints and disciplinary roots.

Pinar's (2004) introduction of the metaphor of conversation touches on the significance of epistemological roots. He argues,

Curriculum becomes a complicated, that is, multiply referenced, conversation in which interlocutors are speaking not only among themselves but to those not present, not only historical figures and unnamed peoples and places they may be studying, but to politicians and parents alive and dead, not to mention to the selves they have been, are in the process of becoming, and someday may become. (Pinar, 2004, p. 43)

Pinar's invocation of history can be understood in two, closely related ways.

First, curriculum conversations are informed by past scholarship and should be historically grounded. In other words, contemporary curriculum inquiry must be conceptualized as one aspect of a larger, multi-referenced conversation. A particular conversation is informed by its historical antecedents and, in turn, contributes to the broader growth of understanding. Second, the epistemology of interlocutors must be taken into consideration when framing a conversation. Each interlocutor has his or her own history, which lends cognitive and linguistic frames of understanding. In an open conversation, each depends upon the other's dissimilar frames and beliefs to expand his or her ways of knowing. Further, a generative curriculum conversation is necessarily inclusive of different traditions and disciplines. We present our dialogue, our ways of knowing, in the form of essay as would be appropriate to the respective academic fields from which these ideas stem. 
While we expected our conversation to enrich our understanding of the topic of fear in relation to learning, we did not, and could not, predict whether we would reach agreement. The discussion lasted until there were no new points of argument. We allowed the conversation to run its full course, without interruption, prior to our analysis of it. This paper follows this same format; the discussion is presented in full, in different fonts for simplification, followed by our analysis of it, which was undertaken jointly.

\section{Judy: It is not Learning That I Fear}

"I'm scared," I said on the first day of my PhD program in the Faculty of Education.

"Learning is fearful," said Theodore.

Instantly, I disagreed. Yet here I was in a learning situation, speaking out loud of terror. Was it my new task of learning curriculum studies that had caused the sense of panic?

I did not fear failing the program but, to an extent, I feared I might fail to reach my own goals, to please those who might have influence over my future, and to avoid negative thoughts and emotions. There was also anxiety regarding social interaction, which boiled down to a concern that I might not fit into this community. Both concerns relate to the specific context of formal education, not the learning itself. My fears then, as now, are about the lack of control over my environment that learning cannot fully address. In contrast, the formal learning undertaken thus far in my $\mathrm{PhD}$ program has been thrilling. It has, in its various guises, challenged and changed my thoughts and opinions. For me, change is exciting, and challenges to my worldview invigorating.

\section{Theodore: Learning is Inherently Fearful}

Learning is inherently fearful. It requires us to leap from the known to the unknown and from the familiar to the unfamiliar. Significant learning exiles us from who we are and from our surroundings. It qualitatively changes us, and it moves us into foreign terrain, real or perceived. This realization seems embedded in the nucleus of Judeo-Christian faith. Adam and Eve were exiled from Eden upon their sampling of the fruit from the tree of learning. They consequently moved from a world of secure plenty to a world dangerous and unknown. They learned to fearto hate, even - the snake, which lured them to consume the fruit of learning. When Adam and Eve learned they were naked, they were fearful of facing their God, and their sentient existence became onerous.

Learning is to be feared. Moses resisted embracing the knowledge of his birth and heritage. He trembled at the thought of leading the Israelites out of Egypt. Moses was raised to believe that he was an Egyptian prince; he was comfortable with his self-knowledge, despite its limitations and its chiasmic distance from the truth. Any knowledge to the contrary would threaten his position and its associate comforts.

\section{Judy: Fear is not Inherent in Learning}

The roots of learning evolved at least 400 million years ago (Poinar, 2011). Learning is a fundamental aspect of multicellular life. We as a species might be particularly good at it, but this talent is a matter of degree. Some of what we understand about learning has been discovered in soil, or more accurately from a common inhabitant of soil, the nematode Caenorhabditis elegans. This simple worm's diminutive size, less than one millimeter in length, belies its importance to science. This worm, with its complement of 302 nerve cells, has taught us much about the 
evolution of learning. For C. elegans is an invertebrate lab rat, and the first multicellular organism to have its entire genome sequenced (The C. elegans Sequencing Consortium, 1998).

In one experiment, $C$. elegans individuals were placed in a T-maze and a drop of water containing bacteria was added to one end of the $\mathrm{T}$ at a detectable distance (Qin \& Wheeler, 2007). The worm learned which side of the maze contained the food. It associated the presence of food with location, and that association was stored in its body for a period of time. The worm remembered, and it acted in accordance with the memory by favouring the food side of the $\mathrm{T}$ maze in future tests. This neurological feat is associative learning. More broadly, learning in a biological sense can be defined as the adaptation of an individual to its environment (Ackley \& Littman, 1991; Thorpe, 1963).

As the environment is rarely, if ever, a static place, learning increases the benefits and decreases the costs incurred by an organism from variation in its surroundings. For wild $C$. elegans, learning where food is located results in more food with less effort. Increased ability to learn is selected in a gene pool when conditions of variable environment and predictable cues are present (Mery \& Kalwecki, 2002).

I am not a nematode. However, my learning, like that of all humans, is a derivative of worm learning. The same neurotransmitters, such as serotonin and dopamine (Chase \& Koelle, 2007), function in similar ways in mammals, including humans (Clark \& Grunstein, 2000; Attar, Finckh, \& Buchel, 2012), as they do in invertebrates like C. elegans.

From an evolutionary perspective, the idea of fear as inherent in learning is contrary to principles of natural selection, given that learning is of benefit in an evolutionary sense. The biological definition of learning is adaptive behaviour to one's environment. Consequently, the suggestion that fear is inherent in learning is equivalent to claiming that fear is inherent in eating. From my perspective, this logic is not stable. Avoidance of learning, as avoidance of eating, is a trait that is not sustainable to any large degree in a population's gene pool over time. Learning individuals will survive to a greater extent than nonlearning individuals by definition, because they are better adapted to their environment. A mutation that results in significant decrease in a nematode's ability to learn will be limited in the gene pool though variation persists in this trait, as in all traits.

Studies of animal behaviour and physiology link curiosity, a chief driver of learning, with exploration and pleasure. Curiosity is a state identified in vertebrates, characterized by exploratory and/or playful behaviour (Gottlieb, Oudeyer, Lopes, \& Baranes, 2013). In exploration, "sense organs are brought into contact with biologically neutral or 'indifferent' stimulus patterns-that is, with objects or events that do not seem to be inherently beneficial or noxious" (Berlyne, 1966, p. 1). Animals exhibit such exploratory behaviour for a significant proportion of their waking hours, regardless of whether there is immediate, practical benefit (Berlyne, 1966). Chimpanzees investigate video cameras, lab rats explore mazes, and Paleolithic humans wandered across the Bering Strait land bridge, exploring unfamiliar territory. Animals, including us, are drawn to strangeness, to incongruity, to complexity, though this preference disappears in conditions of high stimulation (Berlyne, 1966) and its propensity varies with personality (Massen, Antonides, Arnold, Bionda \& Koski, 2013). We have a Knowledge Instinct, an innate drive to learn and to make sense of our environment (Perlovsky, 2010).

Psychology experiments with college students have examined the connection between curiosity, knowledge acquisition, and pleasure. Subjects asked to rate their curiosity for a series 
of questions and then to rate their pleasure at receiving the answer, report that the satisfaction of curiosity (i.e., learning) is pleasurable and that the greater the curiosity, the greater the pleasure (Perlovsky, Bonniot-Cabanac, \& Cabanac, 2010). Neuroscience lends further evidence of a direct learning-pleasure connection, demonstrating via fMRI that the region of the brain associated with reward — the striatum — is activated during learning (Kang et al., 2009).

Fear is an emotional state associated with a coordinated system of responses in response to perceived threat (Boissy, 1995; Nesse, 1990). It is the precursor to avoidance, to fighting or fleeing, which amounts to making a change in our relationship to the environment (Nesse, 1990). The feeling of fear is a negative sensation for the majority of individuals, if the threat is perceived to be real (Rolls, 1999). Like learning, fear is a trait of other mammals (Boissy, 1995). Yet accepting the existence of emotions, like fear, in nonmammals is problematic. Consider again $C$. elegans, the learning nematode. If we are to accept that learning is inherently frightening, we must also accept that $C$. elegans feels fear. If we are not prepared to accept the presence of emotion in nematodes, we cannot conclude that fear is inherent in learning.

Unlike nematodes, human beings are complex, learning, emotional entities. Perhaps fear is inherent in the kind of learning humans do, rather than the simpler, invertebrate kind. How fearful humans are differs between us, as a result of the genes we are born with (Tellegen et al., 1986), our experiences (Herman, 1997), and our parents' experiences (Dias \& Ressler, 2014). Our gender and our age (Ferraro \& LaGrange, 1991) also influence how readily we scare. This plasticity and variation is congruent with fear as an emotional and physiological phenomenon related to, but decoupled from, learning in us as well as worms.

\section{Theodore: Learning is Transformative}

Moses did learn to lead, despite his fear. To do so, he drew on faith. Open-eyed, he pushed forward towards revelations previously unimaginable. His case demonstrates that fear and trembling is inherently intertwined with learning. It also shows the transformation wrought by the leap of faith required to learn. This is manifested most literally in Cecil B. DeMille's (1956) film The Ten Commandments, which recounts the ancient biblical narrative from Exodus. Moses, portrayed by Charlton Heston, climbs Mount Horeb to sacred ground, where the voice of God echoes forth from a bush consumed by fire that does not burn. When Moses returns to his people, he holds stone tablets inscribed with God's law. He has visibly changed. His hair has turned white, his eyes blaze, and his stature becomes commanding. His transformation is obvious to everyone who sees him

Not all learning is of this biblical sort and the transformation that learning provokes is not always apparent and literal. When I was in the sixth grade, for instance, I learned that whales have blowholes. This startled me, yet my hair did not turn white, and my eyes remained unaltered. The same year, when I learned that whales are mammals I had twinges of difficulty, but I could exercise faith in the textbook and the teacher and accommodate the new knowledge into my belief system by shuffling some rather inert facts around my mental cupboard. Whether whales were mammal or fish was of no consequence to me. But when this same teacher showed us a video explaining how whales had evolved from wolf-like creatures, I nearly choked. This fact made no sense in my mind, which was stamped with a Greek Orthodox mindset.

I could not fit this fact anywhere. To do so meant (or would mean), I had to revise my entire cognitive structure and rethink who I was as a human being in this place called life. My mental cupboard would need a total renovation. In the sixth grade, confronting scientific 
evidence on whales' evolution was challenging. Since then, it has filled me with trepidation to learn about evolutionary biology and to try to reconcile it with my own Christian ontology. This is the territory of fear and trembling.

\section{Judy: Anxiety Prevents Learning: The Familiarity That Comes With Learning Assuages Fear}

Fear and exploratory behaviour are in conflict in animals (Corey, 1978), suggesting that anxiety prevents learning, rather than being a necessary precedent. Studies show the conflicting drives of curiosity and fear are both elicited by novel situations (Corey, 1978; Mällo, Alttoa, Kõiv, Tõnissaar, Eller, \& Harro, 2007). Familiarity elicits pleasure (Corey, 1978) and a fear response to new situations is ameliorated with the presence of the familiar (Corey, 1978; Miller, Bard, Juno, \& Nadler, 1986). Fear response is characterized by avoidance behaviour - the opposite of exploratory behaviour, and is associated with anxiety and stress (Harro, Kiivet, Lang, \& Vasar, 1990). Fear, then, in at least some respects, blocks the precursors of learning-curiosity and exploration. The familiarity that comes with learning, however, soothes fear.

If learning itself is not inherently frightening, perhaps other universal correlates of learning evoke the emotion. Learning involves change - in the brain and in behaviour. For humans these changes amount to transformations. Expectation of uncertain change could cause some people anxiety in as much as uncertainty causes anxiety. Individual rats differ in their response to uncertainly. Some rats are highly anxious and have low exploration tendency. Others tend to be much less anxious and be highly exploratory (Mallo et al., 2007). In other words, individual rats are more or less fearful of new situations, and these differences are associated with differences in the brain, dopamine levels for one (Mallo et al., 2007). If rats differ in personality in this way, it is likely that individual humans do too. Uncertainty will be anxiety producing - fearful - for some but not for others. The point remains: learning is not inherently fearful.

\section{Theodore: Fear is Inextricably Linked to Education.}

Fear, I argue, is the root of education. Unrest led Eve to the apple, and provoked Moses' revelation of his true identity. In the history of education, unrest is most evident in the rhetoric of progressive education, which has been the subject of my research for the past seven years. Progressive education is not an entirely historical phenomenon. We know the latter by its moniker, or slogan, 21st century learning.

Consistently, progressivists argue that the current age is qualitatively and quantitatively different than the one that preceded it. Alarmingly, the age to come will be exponentially different. Schools, consequently, need to be re-conceptualized. Progressive education is a pedagogical response to an existential realization: The world we inhabit today is qualitatively different from the one that we inhabited as children. Purposively, it serves as the means by which we might align schools more meaningfully with the qualitatively inimitable world of the present. It is, further, an instrument of change within a rapidly changing world. Progressivist pedagogical philosophy, in other words, is philosophically grounded in anxiety regarding the relationship of schools to social reality; operationalized, however, it is the catalyst for greater dissonance in that relationship.

Ronald Wright's (2004) Massey Lecture, A Short History of Progress develops a twopronged argument. The first is relatively uncontroversial: The social world that we inhabit is 
changing. The second is bolder, but also more exciting: The social world that we inhabit is changing at an increasingly accelerated rate, which renders the taken-for-granted world unrecognizable to us with alarming quickness. From the Palaeolithic era to the end of the last ice age, a span consuming $99.5 \%$ of human existence, tools, and cultural ideals replicated, evolving at a staggeringly slow pace. "Nowadays," Wright (2004) argues, "we have reached such a pass that the skills and mores we learn in childhood are out-dated by the time we're thirty, and few people past fifty can keep up with their culture-whether in idiom, attitudes, taste, or technology - even if they try" (p. 14).

The world is changing. Within an epistemological framework informed by Charles Darwin's evolutionary model, we know if we are to thrive, we must adapt to the world as readily as it randomly and efficiently renovates and revises itself. Educationists are, thus, enveloped within a continuum that stretches from the traditionalist to the progressivist. The first position argues that we must stand strong and lean upon those beliefs and customs that have allowed us to survive and thrive. The latter position says that we must flee the past, let it be disassembled, because it is both moribund and obsolete. The progressivist mindset, which predominates, dictates that life evolves and that our institutions and we must keep pace.

As noted above, technology is not only an exemplar of rapid social change but also it is the very thing that promises to help us mediate that change in the future. Today, technologies are framed as necessary media in an educational life. Society evolves quickly and inexorably, and technology stands as the most apparent metaphor for that evolution.

To be fair, humans have always clung to technologies of various sorts for salvation. What distinguishes us from our forebears, perhaps, is the intensity with which we cling to the promise. This promise holds that as the world transforms in unpredictable ways, technology will evolve apace with that transformation. It promises to mediate the uncertain future for us in increasingly sophisticated ways. It promises to mediate our fear.

Without this promise, we may conceptualize our future in apocalyptic terms. We do so with great regularity. How else might we explain the roaring success of the AMC series The Walking Dead and, with it, the entire zombie genre? Apocalyptic projections are not unreasonable. The polar ice caps are melting, and poverty, famine, disease, and war continue unabated. We cannot be blamed for turning to education - the projection of ourselves into the future and the attempt to manipulate or control what is to come - as a means of planning our salvation.

\section{Judy: People Want to Reduce Uncertainty and Resist What is New: Human Beings are Also Highly Flexible and Learn Readily}

While learning can be defined as adaptive behaviour of individuals to their environment, a collection of individuals may also be described as learning. Such societal change in behaviour is termed cultural evolution. As evolutionary ecologists Molleman, Pen, and Weissing (2013) explain:

Models of cultural evolution use insights from theories of genetic evolution to study how cultural variants, such as ideas and beliefs, spread through populations of individuals by social learning. Social learning based on imitating the behaviour of successful individuals can lead to an evolutionary dynamic similar to the spread of alleles under natural selection, whereas learning by 
adopting behaviours from others more randomly leads to a process resembling genetic drift. (p. 1)

Perhaps, in the sense of cultural learning, societies fear learning.

Psychological research (Cialdini \& Goldstein, 2004; Claidiére, Bowler, \& Whiten, 2012) demonstrates that conforming, or adopting the ideas or behaviour of those around you, is common. We are, in general, followers highly influenced by others (Cialdini, 2005). This helps to explain why a group of regular college students in 1971 participating in the Stanford prison experiment (Zimbardo, 2014) were so influenced by their assigned roles of prisoner and prison guard that they became highly-stressed victim and sadistic victimizer in less than six days. It helps to explain why people told by a researcher to inflict electric shocks to the point of torture in an experimental situation will obey, despite witnessing apparent pain as they increase the voltage (Blass, 1999; Milgram, 1973). However, conformity and extent of social influence differs between individuals (Milgram, 1973) and with gender (Santee \& Jackson, 1982). The propensity of individuals in groups to adopt the behaviour of others seems to obey complex rules (Chamley, 2003; Rendell et al., 2011;Vilone, Ramasco, Sánchez, \& San Miguel, 2012 ). These rules include copying a leader, a more technically skilled acquaintance, one who appears to receive a high pay-off for their actions, or, waiting and watching the fate of others who try things first.

One model backed by experimental evidence (Kameda \& Nakanishi, 2002) suggests that multiple strategies of learners are evolutionarily stable and likely to coexist. At any one time, we might expect a proportion of a population in any given instance to conform and use what others do as a compass for their own behaviour, while a proportion of a population instead avoid copying others in favour of learning direct from the environment.

Such models suggest that the complexity of sociality and our interactions with our environment in a curriculum context have the goal of reducing uncertainty, albeit an ultimately unattainable one. Our evolved suite of behaviours that allow us to learn, to adapt to our surroundings, are inevitably imperfect because our surroundings continually change, like shifting sands beneath us. Regardless of whether learning is by imitation of others or individual/group exploration, the act and the adaption serves the same purpose: reducing uncertainty. Again, through this lens of evolution of social learning, in as much as uncertainty contributes to fear, learning is a balm, not a cause.

It is valid to consider human beings a rapidly adapting species, with cultural evolution occurring at an impressive clip in the last 100,000 years or so (Kobayashi \& Aoki, 2012; Tennie, Call, \& Tomasello, 2009). In this sense, it is difficult to declare outright humanity resistant and fearful of change. Relatively speaking, we embrace it. Yet, no matter how rapidly we adapt culturally, it will not be fast enough. From an evolutionary standpoint, cultural evolution in the realm of education, as elsewhere, is inevitable. Changes in behaviour are expected, but there will never be an ideal reached. Like Lewis Carroll's Red Queen, we will always be "running to stand still."

\section{Theodore: Fear is noble}

Fear is, I argue, a natural state of life inexorably tied to education. Further, education is those personal struggles that we engage in order to subdue our fear. Regardless if we are Moses or a sixth grade student learning about whale evolution, our lifelong, existential, and quotidian struggle to overcome fear is what makes life livable and noble (Cooper \& Fosl, 2009; 
Kierkegaard, 2010; Marino, 2004). Education is, at its very best - at its very substancedissonance, conflict, and unrest. I do not mean that education is a threat to physical or emotional security but, rather, that it is a disruption, an unsettling, and an overturning. The best and most worthy of educative experiences are transformative. They slip outside the parameters of safety. They require dramatic and epic leaps of faith. As Kierkegard (2005) reminds us, this leap of faith puts us in a place of fear and trembling. It is an irrational space that requires greater courage of heart than power of reasoning. These are not mental concepts; they are, as Dickinson (date) writes, "forms of life, practices and passions, which could only be opened in relationship. In Fear and Trembling, Kierkegaard (2005) seeks to reawaken the difficulty of these practices" (p. 88). One must perpetually be unsettled; one must ceaselessly exercise in order to learn.

\section{Judy: Learning is Natural and Pleasant}

Taking an ethologist's perspective (Tinbergen, 1951), observing "wild" human behaviour may offer evidence for answering the question of the emotional impact of learning. In a learning situation outside the formal setting of school, do people exhibit fear? My own childhood, spent in a northern mining town devoid of appropriate parenting, was full of fear and uncertainty. Learning was a source of comfort and pleasure, alleviating both fear and uncertainty. Reading books about worlds removed from my own and the people who studied them, like the ocean floor and Ancient Egypt, not only provided escape and a measure of agency in my immediate environment but also hope for my future. Learning in a less formal sense, perhaps more importantly, was imperative for avoiding sources of fear. Learning about my environment, and myself was crucial for navigating through it alive. The woods are dark, and predators lurk. Leaches wait in the swamps, and blizzards surprise. Knowing the lay of the land, the habits of predators, where the leaches are thickest, and how to read the signs of weather make living in the woods a far less fearful place than it could be.

\section{Theodore: Fear, Faith, and Despair are Intertwined}

As a teacher, I have despaired. As a student, I have felt, frequently, strained to the point of breaking. As a citizen of the world, I have wept at injustices and passed hours in vigils, candles ablaze. Much has made me ache. But without the beckoning and outstretched arms of a better hope, a stronger faith, a more thoughtful approach to living, as well as a more moral and ethically defensible approach to education, I could never persevere through those times that Grayling (2007) terms the moments that "darkness falls" (p. 55).

Throughout the most profound of all my teaching and learning experiences, I have been fraught with fear. The magic realist, Jose Saramago (1999), reminds us in many of his beautiful novels, we must undergo long journeys to travel very short distances. Reconfiguring a Talmudic expression on the belief that a whole heart was necessarily a broken heart, Elie Wiesel (as cited in Monda, 2007) has noted that the only complete and whole faith is a broken faith; this is to say that our faith in the transformative potential of education must be, itself, transformed, tested, and tried by the brutal realities of life's unrest in order to truly orient itself towards a vision of schooling that aims for ideals derided too often by skeptics and by relativist schemes such as love, faith, justice, and peace.

We are unable to close the doors and windows of classroom or mind and dispel all responsibility for the disturbingly epic travesties against humanity and earth outside our classroom, self, and hearth. The world is full of fear and trembling; as educationists we have a significant role to play in enclosing such injustices, ills, and disturbances into spaces of learning 
and wrestling with them, frequently. Abdication of this role is akin to ignoring those people and places that occupy "the darkest part of the dark" (Grayling, 2007, p. 55). Grayling's (2007) thoughts are provocative:

Knowing how little comfort there is in such times should make us more conscious of the agony and isolation of others travelling the dark stretches; and might prompt us to offer them the one thing that brings a small touch of light, like the glimmer of a firefly, into that night - which is one's company and kindness, if sensitively given. (pp. 55-56)

The company and kindness that I might be best inclined to consider educational, in times heavy and associated with fear, is the assumption of responsibility and complicity we each have for the state of the world. Even a firefly's glimmer of light can illuminate dark terrain.

\section{Discussion}

Curriculum is enabled by diversity. It is because of our differences, rather than despite them, that we have learned about ourselves and about the potential for conversation to curate curriculum inquiry. We see our curriculum conversation on fear and learning as a meeting space that we shared while maintaining our unique epistemological perspectives.

Theodore was unable to convince Judy that learning was a frightful thing. He used all of the references that he could draw on, recent and biblical. He was aware that he drew on warrants that were, perhaps, unfamiliar to her, and he cited these warrants in a way consistent with his philosophical background. As Theodore read Judy's responses, the evidence that she drew upon and her reticence to accept his point of view, he realized the conversation had permitted him the opportunity to explore his own beliefs more thoroughly because he was forced to draw on a variety of arguments and repeatedly explain himself in an effort to be comprehensible to his interlocutor. Judy served as a foil to Theodore, so that his opinion only became more entrenched and clear as a consequence of the conversation with another who saw the world differently and used a different language to make sense of that world.

Through this conversation, Judy realized for the first time the strength and breadth of the impact of her epistemological roots on her opinions. Her training in evolution has led to an inevitable approach to inquiry, be it in curriculum, critical theory, or science, which starts with a foundation of understanding behaviour first and foremost by considering whether it is inherited and how it came to be so. Furthermore, tangentially, she also realized that her own experiences growing up in a hostile environment have, in part, led to the importance of this view to her psyche. The epistemological stance that evolution is a powerful shaper of human behaviour fosters and supports an internal locus of control that gives her agency. Having a discussion about fear and learning with Theodore provided impetus for exploration into this view in a way that required rigour and depth of thought not possible in discussion with another evolutionary biologist. By listening to Theodore's unshakable position until she understood his perspective, Judy experienced, rather than merely reading about, other ways of knowing. The result was an understanding of two parallel, irreconcilable positions, both valid, both elucidating understanding on a question of concrete human experience.

In hindsight, we understand that we sought after what Scott (2009) termed "epistemological multilingualism." To be epistemologically multilingual is a challenge on two fronts. First, we require exposure to another's epistemology, although this in itself may not 
suffice to provoke understanding. Second, we must engage with different epistemologies, although if they are vastly different from our own, this engagement may serve to deepen the epistemological divide between self and other. As our conversation unfolded, we began to see that, despite our greatest efforts, we were seeing the world differently and continuing to use a different language to represent that world; further, as Scott (2009) argues, we found that there was a great benefit to seeking to understand others' languages, to the point of being able to employ them.

Stephen Pepper (1942) describes differing worldviews in World Hypotheses. We see the world through a lens, or worldview, which Pepper describes as emerging from distinct "root metaphors" and, consequently, there are various ways to understand and to interpret what we see (p. 84). As Nozick (1981) stated:

There are various philosophical views, mutually incompatible, which cannot be dismissed or simply rejected. Philosophy's output is the basketful of these admissible views, all together. One's delimiting strategy would be to modify and shave these views, capturing what is true in each, to make them compatible parts of one new view. While I know of no reason in principle why this cannot be done, neither has anyone yet done it satisfactorily. Perhaps, as knowing a subject (such as logic or physics) involves seeing the different ways it can be organized and viewed, the different ways around it, so too (only this time the views are incompatible so the analogy is imperfect) knowing the world involves seeing the different ways it can be viewed. (p. 21)

Consensus is not possible or desirable, just as the mixing of metaphors muddies the meaning of both.

One realization that arose from this conversation is the extent our epistemologies inform our opinions and our approach. "What then is education?" asks Søren Kierkegaard (2005); it is, he argues, "the curriculum the individual ran through in order to catch up with himself [sic]; and anyone who does not want to go through this curriculum will be little helped by being born into the most enlightened age" (p. 52). We have both recognized how our ingrained epistemologies influence our worldviews, and our cognitive and linguistic frames.

We differ fundamentally in our philosophical stance on knowledge. We attribute disparate connotations to words, and we diverge in our perception of the contexts where learning takes place. Judy emphasizes natural conditions; Theodore emphasizes lived experiences. These elements complicated our conversation but they also necessitated an ongoing demand that we cultivate empathy for and understanding of a perspective different from our own, in order to continue the conversation. Moreover, while our actual ideas concerning fear and learning remained somewhat static, our reflexivity regarding perspectival view of the world and our understanding of our positionality as curriculum scholars was cultivated. As Scott (2009) suggests, the increased globalization of our world means that conversations between education scholars, education scholars and educators, and educators and students involve increasingly disparate worldviews. Finding a way to be inclusive of others' worldviews means being willing and able to engage in conversation with them, without expectation of accord. A curriculum that provides students, teachers, and scholars with opportunities for such conversations also supports what Scott (2009) calls, “development of sense of self” (p. 52). 
We are unable to escape our perspectives, despite viewing the problem from another's point of view and hence appreciating its unique contributions. As a consequence, we have assumed a perspectivist stance to understand our curriculum conversation. Pearce (2013) explains this stance succinctly:

Perspectivism is best outlined with direct reference to the notion of truth. For an absolutist, a proposition is either true or not true. Relativists, on the other hand, are more hostile to the notion of truth. For a relativist, any proposition (or a number of them) can be true, if so chosen, or if constructed in some way....However, for a perspectivist, it is not that any proposition can be true, rather than truth is always perspectival - it is always related to certain vantage points. That is, truth always depends on some evaluative background. (pp. 533534)

Radick (2009) elaborates within the scientific context: "Our probings are always limited by the standpoints that our observational and theoretical instruments define" (p. 206). Our perspectives include all facets of our selves, including our senses, our personal histories, and our ambitions.

In acknowledging a distinction between philosophy and science as ways of knowing, we follow from the ideas forwarded by Socrates in Plato's (trans. 2001) Apology. This text, a classical Athenian courtroom drama, outlines how Socrates draws a line between himself and natural philosophers. Pre-Socratic philosophy was aligned ontologically and epistemologically with what is contemporarily understood as a materialist study of the universe. Socrates does not disparage natural philosophy_-science - but distinguishes his understanding of the world from that perspective, primarily because the foundation of his philosophical framework was the acknowledgment of his own ignorance. His paradoxical contention that knowledge depended upon the realization that knowledge, understood in the broadest sense, was impossible separated him from those natural philosophers that believed that they could incrementally build deeper and richer understandings of the world and phenomena around them. Philosophy, seen from a Socratic lens, offers no certainty. Science, at least from a critical realist standpoint, provides tangible facets of understanding (Bhaskar, 2008).

Despite our differences, our learning was enriched by this conversation. Through this exploration, we did find tangential points on which we could agree. We agreed that the greater context of formal education influences students' fear. We also agreed that the context in which an individual learns influences fear's value - its significance to life. A child who does not fear fire who touches a hot coal will not quickly forget. A soldier who does not fear death is mad, not brave. From the philosopher's perspective, these illustrations relate to how we ought to live. They are demonstrative of the power of faith, which cannot exist without fear. From the biologist's perspective, fear is adaptive; its benefit to the organism is more apparent in some situations, such as playing near fire and preparing for battle.

\section{Conclusion}

We cannot reach a consensus regarding the relationship of fear to learning. Our epistemological frameworks deeply and irrevocably influenced our study and our understanding of the topic, the language we used to communicate about it, and the conclusions we drew. Through conversation, we deepened our own understanding of the topic, and gleaned new perspective on curriculum itself. Furthermore, through conversation we entered in relation. Conversation is for Buber (1937), the source of the I-Thou, as opposed to the I-It: "In the form of speech. We can give and 
accept the Thou" (p. 6). The I-thou relationship is transformational, when neither of the two entities is to be understood piecemeal or as an object put to some purpose, but rather as a whole other. Human beings and their perspectives are not just conduits to further empirical truths, but irreducible truths in their own right. 


\section{References}

Ackley, D., \& Littman, M. (1991). Interactions between learning and evolution. In C.G. Langton, C. Taylor, J. D. Farmer, \& S. Rasmussen (Eds.) Artificial Life II, SFI studies in the sciences of complexity, (Vol. x., pp. 487-509). Boston, MS: Addison-Wesley.

Attar, C. H., Finckh, B., Buchel, C. (2012). The influence of serotonin on fear learning. PLoS One 7(8): e42397. doi:10.1371/journal.pone.0042397

Berlyne, D. E. (1966). Curiosity and exploration. Science, 153(3731), 25-33.

Bhaskar, R. (2008). A realist theory of science. New York, NY: Verso.

Blass, T. (1999). The Milgram paradigm after 35 years: Some things we now know about obedience to authority. Journal of Applied Social Psychology, 29(5), 955-978.

Boissy, A. (1995). Fear and fearfulness in animals. The Quarterly Review of Biology, 70(2), 16591.

Buber, M. (1937). I and Thou (R. G. Smith, Trans.). Edinburgh, SCT: T. \& T. Clark. (Original work published 1923) Retrieved from http://www.tjdonovanart.com/Martin\%20Buber\%20\%20I\%20And\%20Thou\%20(c1923\%20127P).pdf

Chamley, C. P. (2003). Rational herds: Economic models of social learning. Cambridge, UK: Cambridge University Press.

Chase, D. L., \& Koelle, M. R. (2007). Biogenic amine neurotransmitters in C. elegans. WormBook, 20, 1-15. doi/10.1895.wormbook.1.132.1

Christou, T., \& DeLuca, C. (2013). Curriculum studies at a crossroad: Curating inclusive and coherent curriculum conversations in Canada. Journal of the Canadian Association for Curriculum Studies, 11(1), pp. 13-22.

Cialdini, R. B. (2005). Basic social influence is underestimated. Psychological Inquiry, 16(4), $158-161$.

Cialdini R. B., \& Goldstein, N. J. (2004). Social influence: Compliance and conformity. Annual Review of Psychology, 55, 591-621.

Claidière, N., Bowler, M., \& Whiten, A. (2012). Evidence for weak or linear conformity but not for hyper-conformity in an everyday social learning context. PLOS ONE, 7(2), e30970. doi:10.1371/journal.pone.0030970

Clark, W. R., \& Grunstein, M. (2000). Are we hardwired? The role of genes in human behavior. Oxford, UK: Oxford University Press.

Cooper, D. E., \& Fosl, P. S. (Eds.) (2009). Philosophy: The classic readings. Malden: WileyBlackwell.

Corey, D. T. (1978). The determinants of exploration and neophobia. Neuroscience and Biobehavioral Reviews, 2, 235-253.

Dewey, J. (1938). Experience and education. New York, NY: Touchstone. 
DeMille, C. B. (Producer, Director). (1956). The ten commandments.[Motion Picture]. Hollywood, CA: Paramount Pictures.

Dias, B. G., \& Ressler, K. J. (2014). Parental olfactory experience influences behavior and neural structure in subsequent generations. Nature Neuroscience, 17(1), 89-96. doi:10.1038/nn.3594

Dickinson, T. W. (2012). Teaching with fear and trembling: The trial of Abraham, the reader, and the professor. Journal for Cultural and Religious Theory, 12(2), 85-105.

Ferraro, K. F., \& LaGrange, R. L. (1991). Are older people most afraid of crime? Reconsidering age differences in fear of victimization. Journal of Gerontology, 47(5), S233-S244.

Gergen, J., \& Jones, K. (2008). Editorial: A conversation about performative social science. Qualitative Social Research, 9(2), Art. 43. Retrieved from http://nbnresolving.de/urn:nbn:de:0114-fqs0802437

Gottlieb, J., Oudeyer, P.Y., Lopes, M., \& Baranes, A. (2013). Information-seeking, curiosity, and attention: computational and neural mechanisms. Trends in Cognitive Science, 17(11), $585-596$.

Grayling, A. C. (2007). The choice of Hercules: Pleasure, duty, and the good life in the $21^{\text {st }}$ century. London, UK: Weidenfeld \& Nicolson.

Harro, J., Kiivet, R. A., Lang, A., \& Vasar, E. (1990). Rats with anxious or non-anxious type of exploratory behaviour differ in their brain CCK-8 and benzodiazepine receptor characteristics. Behavioural Brain Research, 39(1), 63-71.

Herman, J. L. (1997). Trauma and recovery. New York, NY: Basic Books.

Jardine, D.W., \& Ross, S. M. (2009). Won by a certain labour: A conversation on the while of things. Journal of the American Association for the Advancement of Curriculum Studies, 5. Retrieved from www2.uwstout.edu/content/jaaacs/Vol5/Ross_Jardine.pdf

Kameda, T., \& Nakanishi, D. (2002). Cost-benefit analysis of social/cultural learning in a nonstationary uncertain environment: An evolutionary simulation and an experiment with human subjects. Evolution and Human Behavior, 23(5), 373-393. doi:10.1016/S1090$\underline{5138(02) 00101-0}$

Kang, M. J., Hsu, M., Krajbich, I. M., Loewenstein, G., McClure, S. M., Wang, J. T., \& Camerer, C. F. (2009). The wick in the candle of learning epistemic curiosity activates reward circuitry and enhances memory. Psychological Science, 20(8), 963-973.

Kierkegaard, S. (2005). Fear and trembling (A. Hannay, Trans.). New York, NY: Penguin.

Kierkegaard, S. (2010). Kierkegaard's journals and notebooks (Vol. 3, Notebooks 1-15). N. J. Cappelørn et al. (Eds.). Princeton, NJ: Princeton University Press.

Kobayashi, Y., \& Aoki, K. (2012). Innovativeness, population size and cumulative cultural evolution. Theoretical Population Biology, 82(1), 38-47.

Lund, D. E., \& Veinotte, C. (2010). Researching a social justice course in a charter school: A duoethnographic conversation. in education, 16(2), 5-13. 
Mällo, T., Alttoa, A., Kõiv, K., Tõnissaar, M., Eller, M., \& Harro, J. (2007). Rats with persistently low or high exploratory activity: behaviour in tests of anxiety and depression, and extracellular levels of dopamine. Behavioral Brain Research, 177(2), 269-81.

Marino, G. (Ed.) (2004). Basic writings of existentialism. New York, NY: Modern Library.

Massen, J. J. M., Antonides, A., Arnold, A. K., Bionda, B., \& Koski, S. E. (2013). A behavioral view on chimpanzee personality: Exploration tendency, persistence, boldness, and tool orientation measured with group experiments. American Journal of Primatology, 75(9), 947-958. doi: 10.1002/ajp.22159

Mery, F., \& Kawecki, T. J. (2012). Experimental evolution of learning ability in fruit flies. Proceedings of the National Academy of Sciences, 99(22), 14274-14279.

Milgram, S. (1973). The perils of obedience. Harper's Magazine, 247(1483), 62-77.

Miller, L. C., Bard, K. A., Juno, C. J., \& Nadler, R. D. (1986). Behavioral responsiveness of young chimpanzees (Pan troglodytes) to a novel environment. Folia Primatologica, 47(2-3), 128-142. doi:10.1159/000156270

Molleman, L., Pen, I., \& Weissing F. J. (2013). Effects of conformism on the cultural evolution of social behaviour. PLOS ONE, 8(7), e68153. doi: 10.1371/journal.pone.0068153

Monda, A. (2007). Do you believe? Conversations on God and religion. New York, NY: Vintage Books.

Nesse, R. M. (1990). Evolutionary explanations of emotions. Human Nature, 1(3), 261-289.

Nozick, R. (1981). Philosophical explanations. Cambridge, MA: Belknap Press.

Pacheco, J. A. (2012). Curriculum studies: What is the field today? Journal of the American Association for the Advancement of Curriculum Studies, 8(1), 1-18.

Pearce, J. V. (2013). The potential for perspectivism for science education. Educational Philosophy and Theory, 45(5), 531-545.

Pepper, S. C. (1942). World hypotheses: A study in evidence. Los Angeles, CA: University of California Press.

Perlovsky, L. I. (2010). Intersections of mathematical, cognitive, and aesthetic theories of mind. Psychology of Aesthetics, Creativity, and the Arts in the Public Domain, 4(1), 11-17.

Perlovsky, L. I., Bonniot-Cabanac, M. C., \& Cabanac, M. (2010, July). Proceedings of Curiosity and Pleasure. IJCNN 2010: International Joint Conference on Neural Networks, Barcelona, Spain.

Pinar, W. F. (2004). What is curriculum theory? Mahwah, NJ: Lawrence Erlbaum.

Plato. (2001). The Apology, Phcedo and Crito. (B. Jowett, Trans.). Harvard Classics, 2(1). New York, NY: P.F. Collier \& Son, 1909-14. Retrieved from www.bartleby.com/2/1/

Poinar, G.O. (2011). The evolutionary history of nematodes. Boston, MS: Brill. 
Qin, J., \& Wheeler, A.R. (2007). Maze exploration and learning in C. elegans. Lap Chip, 7(2), 186-192.

Radick, G. (2009). Book review of Scientific Perspectivism. Isis, 100(1), 206.

Rendell, L., Fogarty, L., Hoppitt, W. J. E., Morgan, T. J. H., Webster, M. M., \& Laland, K. N. (2011). Cognitive culture: Theoretical and empirical insights into social learning strategies. Trends in Cognitive Sciences 15(2), 68-76.

Rolls, E.T. (1999). The Brain and Emotion. Oxford, UK: Oxford University Press.

Sameshima, P., \& Leggo, C. (2013). How do you spell love? Curricular conversations. Creative Approaches to Research, 6(1), pp. 89-109.

Santee, R. T., \& Jackson, S. E. (1982). Identity implications of conformity: Sex differences in normative and attributional judgments. Social Psychology Quarterly, 45(2), 121-125.

Saramago, J. (1999). All the names. (M. J. Costa, Trans.). New York, NY: Harvest Books.

Scott, C. (2009). Epistemological multilingualism: A tool for conviviality. Paideusis, 18(2), 4354.

Tellegen, A., Lykken D. T., Bouchard T. J., Wilcox, K. J., Segal, N. L., \& Rich, S. (1988). Personality similarity in twins reared apart and together. Journal of Personality and Social Psychology, 54(6), 1031-1039.

Tennie, C., Call, J., \& Tomasello, M. (2009). Ratcheting up the ratchet: on the evolution of cumulative culture. Philosophical Transactions of the Royal Society B, 364, 2405-2415. doi:10.1098/rstb.2009.0052

The C. elegans Sequencing Consortium. (1998). Genome sequence of the nematode C. elegans: A platform for investigating biology. Science, 282(5396), 2012-2018.

Thorpe, W. H. (1963). Learning and instinct in animals. London: Methuen.

Tinbergen, N. (1951). The study of instinct. Oxford, UK: Clarendon.

Vilone, D., Ramasco, J. J., Sánchez, A., \& San Miguel, M. (2012). Social and strategic imitation: The way to consensus. Scientific Reports, 2, 686.

Wiebe, S. \& Guiney Yallop, J. J. (2010). Ways of being in teaching: Conversing paths to meaning. Canadian Journal of Education, 33(1), 177-198. Retrieved from http:/files.eric.ed.gov/fulltext/EJ883528.pdf/

Wright, R. (2004). A short history of progress. Toronto, ON: House of Anansi Press.

Zimbardo, P. G. (2014) The Stanford prison experiment. Retrieved from http://www.prisonexp.org/ 